\title{
Green synthesis of copper nanoparticles using Cocoa pod extract and its catalytic activity in deep oxidation of aromatic hydrocarbons
}

\author{
Phung Anh Nguyen ${ }^{1}$ Ai Vi Pham Nguyen ${ }^{2,3} \cdot$ Trung Dang-Bao $^{2,3} \cdot$ Hong Phuong Phan ${ }^{2,3} \cdot$ Thi Thuy Van Nguyen ${ }^{1,4}$. \\ Boi An Tran ${ }^{1,4}$. Thanh Linh Duong Huynh ${ }^{1}$ Tien Cuong Hoang ${ }^{1,4} \cdot$ Van Tien Huynh ${ }^{5}$. Tri Nguyen ${ }^{1,4,6}$
}

Received: 8 May 2020 / Accepted: 17 September 2020 / Published online: 8 October 2020

(c) Springer Nature Switzerland AG 2020

\begin{abstract}
An effective and green technique was performed for the synthesis of copper nanoparticles (CuNPs) from an organic resource using the Cocoa pod (CCP) extract as a reducing agent. The formation of CuNPs was confirmed by ultraviolet-visible absorption spectroscopy (UV-Vis) at the wavelength range of 500-600 $\mathrm{nm}$. The optimized conditions for the synthesis of CuNPs using CCP extract as a reducing agent were determined by the volume ratio of $\mathrm{Cu}\left(\mathrm{NO}_{3}\right)_{2}$ solution/ $\mathrm{CCP}$ extract of 3.5/1.5, stirring rate of $300 \mathrm{rpm}$, pH solution of 7.5 , the temperature of $75^{\circ} \mathrm{C}$ and the synthesis duration within $180 \mathrm{~min}$. At these conditions, the X-ray diffraction result revealed a face-centered cubic structure of zero-valent copper with a highly crystalline and an average size of $34.4 \mathrm{~nm}$. Fourier transform infrared spectroscopy result confirmed the presence of flavonoids, polyphenolic, and alkaloids components in CCP extract which can act as the reducing and stabilizing agents for CuNPs formation. At the optimized synthetic conditions, CuNPs loaded on various supports $\left(\mathrm{Al}_{2} \mathrm{O}_{3}\right.$, $\mathrm{CeO}_{2}$, and $\mathrm{TiO}_{2}$ ) were prepared following the same protocol and then applied for catalytic deep oxidation of aromatic hydrocarbons (AHs). Among them, $\mathrm{CeO}_{2}$ was the best support in $\mathrm{AHs}$ deep oxidation, and the sample of $7.5 \mathrm{Cu}-\mathrm{Ce}$ ( $7.5 \mathrm{wt} \%$ of $\mathrm{CuNPs}$ supported on $\mathrm{CeO}_{2}$ ) was the most efficient. Compared with $5 \mathrm{Cu}-\mathrm{Ce}$ and $10 \mathrm{Cu}-\mathrm{Ce}$, the $7.5 \mathrm{Cu}-\mathrm{Ce}$ sample exhibited a higher benzene conversion at a low temperature $\left(275-325^{\circ} \mathrm{C}\right)$ and reached the full conversions of benzene, toluene, ethylbenzene, and xylene (BTEX) to carbon dioxide and water vapor below $450^{\circ} \mathrm{C}$. Furthermore, the $7.5 \mathrm{Cu}-\mathrm{Ce}$ sample showed great stability for such reactions at $300^{\circ} \mathrm{C}$ as proven by the unchanged conversions of BTEX during $48 \mathrm{~h}$.
\end{abstract}

Keywords Green synthesis · Copper nanoparticles · Cocoa pod · Deep oxidation · Aromatic hydrocarbons

\section{Introduction}

Volatile organic compounds (VOCs) in the atmosphere have been known as a source of contaminants that adversely affect air quality and human health [5, 22]. VOCs have been found to be the major contributing factor to ozone layer depletion, which leads to global warming. With respect to human health, exposure to VOCs may cause respiratory and cardiovascular disease and even devotes to cancer $[5,11]$. Among sources of VOCs spreading, irrespective of natural causes, petroleum refining and petrochemical plants take account for the majority. According to the report from Li et al., benzene, toluene, and acetone were the most abundant emission species from coke production [19]. Zhang et al. measured the emission characteristics of VOCs in different

Tri Nguyen, ntri@ict.vast.vn | ${ }^{1}$ Institute of Chemical Technology, Vietnam Academy of Science and Technology, 01 Mac Dinh Chi Street, Ho Chi Minh City, Vietnam. ${ }^{2}$ Vietnam National University Ho Chi Minh City, Linh Trung Ward, Thu Duc District, Ho Chi Minh City, Vietnam. ${ }^{3} \mathrm{Ho}$ Chi Minh City University of Technology (HCMUT), 268 Ly Thuong Kiet Street, Ho Chi Minh City, Vietnam. ${ }^{4}$ Graduate University of Science and Technology, Vietnam Academy of Science and Technology, Hanoi 100000, Vietnam. ${ }^{5}$ Ho Chi Minh City University of Food Industry, 140 Le Trong Tan Street, Ho Chi Minh City, Vietnam. ${ }^{6} \mathrm{Ho}$ Chi Minh City Open University, 97 Vo Van Tan Street, Ho Chi Minh City, Vietnam. 
areas of a petroleum refinery, showing more than $50 \%$ of the total VOCs emitted from the refining area, including 2-methylpentane, 2,3-dimethylbutane, methylcyclopentane, 3-methylhexane, and butane [39]. Chen et al. found out that the naptha-cracking region mainly produced propene, 1, 3-butadiene, benzene, isobutene, and butane while butane, isobutene, and benzene were the major outputs in the aromatic region [6]. Recently, aromatic hydrocarbons are of the most concern due to their variety, abundance, and toxicity. In fact, benzene, toluene, ethylbenzene, xylene (BTEX) mostly found in natural gas and oil deposits, or in petroleum refining and petrochemical plants $[31,35]$ have harmful impacts on human health. When exposed to more than $100 \mathrm{ppm}$ of benzene (considered as the exposure limit), irritation to eye, nose, and throat, chest tightening, or more serious health symptoms can occur [33].

Catalytic deep oxidation stands out as a practical technology, permitting to effectively remove VOCs in both gaseous and aqueous phase, even at low concentration $[13,38]$, mainly based on catalysts. The catalytic oxidation is promising in the reduction of emissions because it is able to remove the emissions from high to very low levels, which may meet the needs of more stringent emission control in future. Also, compared with thermal incineration processes, the operating temperature of the catalytic oxidation is much lower. This is helpful for avoiding the formation of toxic byproducts and for reducing energy consumption.

More recently, great attention has been paid to copper nanoparticles (CuNPs) thanks to their excellent catalytic performances in VOCs oxidation [17-18, 28]. Various methods for the synthesis of CuNPs have been developed, mainly based on the chemical reduction of metal salts or complexes $[15,30]$. In particular, the plant extracts acting as the reducing agents have been introduced to the bio-synthesis of metal nanoparticles, thanks to their low-cost and non-toxic features. Cocoaoriginating wildly in the tropical forests of Central and South America was introduced to Southeast Asia and Vietnam for a long time. The cocoa pods as the by-product of the cocoa processing (accounting for 52-76 wt\% of the total fruit) are often discarded due to its low market value. Cocoa pods contain many compounds such as gallic acid, alanine, glumatic acid, flavonoids, polyphenols, etc. [8], acting as reducing agents for the synthesis of highly efficient CuNPs [14, 21]. The cocoa extract has also been used as a reducing and stabilizing agent in the biosynthesis of silver [16] and $\mathrm{Pd} / \mathrm{CuO}$ [24] nanoparticles. However, to the best of our knowledge, Cocoa pod extract (CCP extract) has never been reported as reducing and stabilizing agents for the synthesis of CuNPs.
In this paper, CuNPs and CuNPs loaded on various supports $\left(\mathrm{Al}_{2} \mathrm{O}_{3}, \mathrm{CeO}_{2}\right.$, and $\left.\mathrm{TiO}_{2}\right)$ were synthesized from $\mathrm{Cu}\left(\mathrm{NO}_{3}\right)_{2}$ solution using $\mathrm{CCP}$ extract as a reducing agent. The starch was used during synthesis as a stabilizing agent, leading to monodispersed Cu nanoparticles in an aqueous medium as well as stabilizes the Cu nanoparticles from air oxidation. The effects of the synthesis duration, the volume ratio of $\mathrm{Cu}\left(\mathrm{NO}_{3}\right)_{2}$ solution/CCP extract, the stirring rate, $\mathrm{pH}$ solution, and the reaction temperature were assessed. The physico-chemical properties of the obtained CuNPs were investigated. Their catalytic activities were investigated in deep oxidation of aromatic hydrocarbons (AHs) including benzene, toluene, ethylbenzene, and xylene in the gaseous phase.

\section{Experimental}

\subsection{Materials}

Cocoa pods were collected from Tien Giang province, Vietnam. After washing and draining, $50 \mathrm{grs}$ of the Cocoa pods were minced and mixed with $1000 \mathrm{~mL}$ of deionized water. Then, the mixture is heated to $80^{\circ} \mathrm{C}$ for $2 \mathrm{~h}$ under stirring. Finally, the Cocoa pod extract (CCP extract) was filtered and preserved at $4{ }^{\circ} \mathrm{C}$ for the further experiments. Copper(II) nitrate $\left(\mathrm{Cu}\left(\mathrm{NO}_{3}\right)_{2} \cdot 6 \mathrm{H}_{2} \mathrm{O},>99.8 \%\right)$, starch $\left(\left(\mathrm{C}_{6} \mathrm{H}_{10} \mathrm{O}_{5}\right)_{n^{\prime}}>99 \%\right)$ and sodium hydroxide $(\mathrm{NaOH},>99.9 \%)$ were purchased from Merck.

\subsection{Preparation of CuNPs and supported-CuNPs}

The green synthesis of CuNPs was performed by adding $1.5 \mathrm{grs}$ starch to the aqueous solution of $0.02 \mathrm{M} \mathrm{Cu}\left(\mathrm{NO}_{3}\right)_{2}$ with vigorous stirring, leading to the color change from blue to white. Afterward, CCP extract was added to the mixture and the color transformation from white to blue moss occurred in the aqueous phase. $\mathrm{NaOH}$ solution $(0.1 \mathrm{M})$ was added to the reaction mixture under continuous vigorous stirring (200-400 rpm) to adjust the $\mathrm{pH}(8.5-9.5)$ and then heated to the desired temperature $\left(70-80^{\circ} \mathrm{C}\right)$. The formation of the CuNPs is confirmed by the color change from green to brown. The effects of the reaction factors involving the time, volume ratio of $\mathrm{Cu}\left(\mathrm{NO}_{3}\right)_{2}$ solution/CCP extract, stirring rate, $\mathrm{pH}$, and temperature on the CuNPs formation were investigated.

CuNPs loaded on various pre-formed supports $\left(\mathrm{Al}_{2} \mathrm{O}_{3}\right.$, $\mathrm{CeO}_{2}$, and $\mathrm{TiO}_{2}$ ) were in-situ synthesized at the optimized conditions following the same protocol. 


\subsection{Characterization methodology}

The formation of CuNPs in solution was observed by UV-Vis spectrophotometer (UV-1800, Shimadzu) at a scanning speed of $200-800 \mathrm{~nm}$ with a resolution of $1 \mathrm{~nm}$. X-ray powder diffraction (XRD) patterns were collected on Bruker D2 Phaser diffractometer using CuKa radiation $(\lambda=0.154 \mathrm{~nm})$ in $2 \theta=10-80^{\circ}$ with the scanning step of $0.02^{\circ}$. The average crystal size of CuNPs, $d(\mathrm{~nm})$, was calculated according to the Scherrer equation [26]:

$d(n m)=\frac{K \lambda}{\beta \cos \theta}$

where $K$, the Scherrer constant, is taken to be $0.94, \lambda$ is the wavelength of the $X$-ray, $\beta$ is the line width at half maximum height of the peak in radians, and $\theta$ is the position of the peak in radians. The morphology of samples was characterized by scanning electron microscopy (SEM) and Energy Dispersive Spectroscopy (EDS) on JST-IT 200 instrument. The morphology, particle size, and crystal phases were also estimated by HRTEM analysis on JEOL $2100 \mathrm{~F}$ instrument. The CCP extract and the surface of obtained materials were detected by Fourier transform infrared spectroscopy (FT-IR) carried out on a Tensor 27-Bruker spectrophotometer operating in the range of $400-4000 \mathrm{~cm}^{-1}$ at a resolution of $2 \mathrm{~cm}^{-1}$.

\subsection{Catalytic activity in deep oxidation}

The catalytic activity of supported-CuNPs was investigated by the AHs treatment and performed in a fixed tubular quartz reactor (inside diameter of $8 \mathrm{~mm}$ ) under atmospheric pressure at a temperature range of $275-450^{\circ} \mathrm{C}$. The weight hourly space velocity (WHSV) was $60,000 \mathrm{~mL} \mathrm{~h}^{-1} \mathrm{~g}^{-1}$, and the mass of catalyst was 0.2 grs with a size range of $0.25-0.50 \mathrm{~mm}$. The inlet concentrations of AHs and oxygen in nitrogen were 0.34 and $10.5 \mathrm{~mol} \%$, respectively. The reactant and product mixtures were analyzed with an Agilent 6890 Plus Gas Chromatograph with FID detector and capillary column DB-624 (Oven temperature program: isothermal analysis at $150^{\circ} \mathrm{C}$; detector temperature: $300^{\circ} \mathrm{C}$; injector temperature: $250^{\circ} \mathrm{C}$; carrier gas: nitrogen; inlet pressure: $20 \mathrm{PSI})$ and with a TCD detector and capillary column TGBONQ (Oven temperature program: $50^{\circ} \mathrm{C}(5 \mathrm{~min}) \rightarrow 10^{\circ} \mathrm{C} /$ $\min \rightarrow 150^{\circ} \mathrm{C}(5 \mathrm{~min})$; detector temperature: $180^{\circ} \mathrm{C}$; injector temperature: $180^{\circ} \mathrm{C}$; carrier gas: helium; inlet pressure: $5 \mathrm{PSI}$ ). The tests were conducted in triplicate to ensure the accuracy of the results. The AHs conversion was calculated as follows:

$X_{A H s}(\%)=\frac{[A H s]_{\text {in }}-[A H s]_{\text {out }}}{[A H s]_{\text {in }}} \times 100 \%$ where $X_{A H s}(\%)$-AHs conversion; $[A H s]_{\text {in }}$ and $[A H s]_{\text {out }}$-the input and output quantities of $A H s$, respectively.

The most outstanding catalyst was selected for the catalytic stability in the AHs oxidation. The reaction was carried out at $300^{\circ} \mathrm{C}$ for $48 \mathrm{~h}$ and the conversions of $\mathrm{AHs}$ were recorded every $2 \mathrm{~h}$.

\section{Results and discussions}

\subsection{Green synthesis of copper nanoparticles}

The formation of CuNPs was monitored by UV-Vis spectroscopy as shown in Fig. 1. The effect of synthesis duration (see in Fig. 1a) showed that the CuNPs formation takes place at $80^{\circ} \mathrm{C}$ for at least $60 \mathrm{~min}$. The broad peak was observed at a range of $500-600 \mathrm{~nm}$, indicating the formation of CuNPs in the solution. The formation of the CuNPs was also confirmed by the color change from green to brown Fig. 2. Upon the reaction time, the absorbance intensity increased, evidencing the higher conversion of $\mathrm{Cu}^{2+}$ ions to $\mathrm{Cu}^{\circ}$ nanoparticles (CuNPs). The maximum signal intensity attributed to surface plasmon resonance of zero-valent CuNPs was observed at $180 \mathrm{~min}$ and $210 \mathrm{~min}$, confirming the full reduction of $\mathrm{Cu}^{2+}$ to $\mathrm{Cu}^{\circ}$. Therefore, the time of 180 min was chosen for the further characterizations. With the volume ratio of $\mathrm{Cu}\left(\mathrm{NO}_{3}\right)_{2}$ solution/ CCP extract of 3.5/1.5, CuNPs were obtained at the highest performance (see in Fig. 1b). The components in the extract with high concentrations could effectively reduce the $\mathrm{Cu}^{2+}$ ions to $\mathrm{Cu}^{\circ}$, and also act as capping agents to stabilize CuNPs through steric hindrance, thus preventing their aggregation [29]. Figure 1c showed the concentration of the obtained CuNPs increased when the stirring rate increased from 200 to $300 \mathrm{rpm}$, but slightly dropped applying $400 \mathrm{rpm}$. Due to the increase of nanostructure concentration, stronger mixing was essential to provide uniform heat and mass transfer [27]. Besides, CuNPs were detected at the highest absorbance by the UV-Vis spectra at pH 8.5 (see in Fig. 1d) and at the temperature of $75^{\circ} \mathrm{C}$ (see in Fig. 1e).

From the obtained results, the optimized conditions for the synthesis of CuNPs using C.C extract as a reducing agent were determined involving the volume ratio of $\mathrm{Cu}\left(\mathrm{NO}_{3}\right)_{2}$ solution/C.C Extract of 3.5/1.5, stirring rate of $300 \mathrm{rpm}, \mathrm{pH} 7.5$, the temperature of $75^{\circ} \mathrm{C}$ and the synthesis duration of $180 \mathrm{~min}$.

X-ray diffraction analysis (XRD) of CuNPs was shown in Fig. 3a. Three Bragg reflections with $2 \theta=43.6^{\circ}, 50.7^{\circ}$, and $74.4^{\circ}$ were recorded corresponding to (111), (200) and (220) lattice planes, which are characteristics of the facecentered cubic structure of zero-valent copper (JCPDS card No. 04-0836). Besides, a broad diffraction peak at 

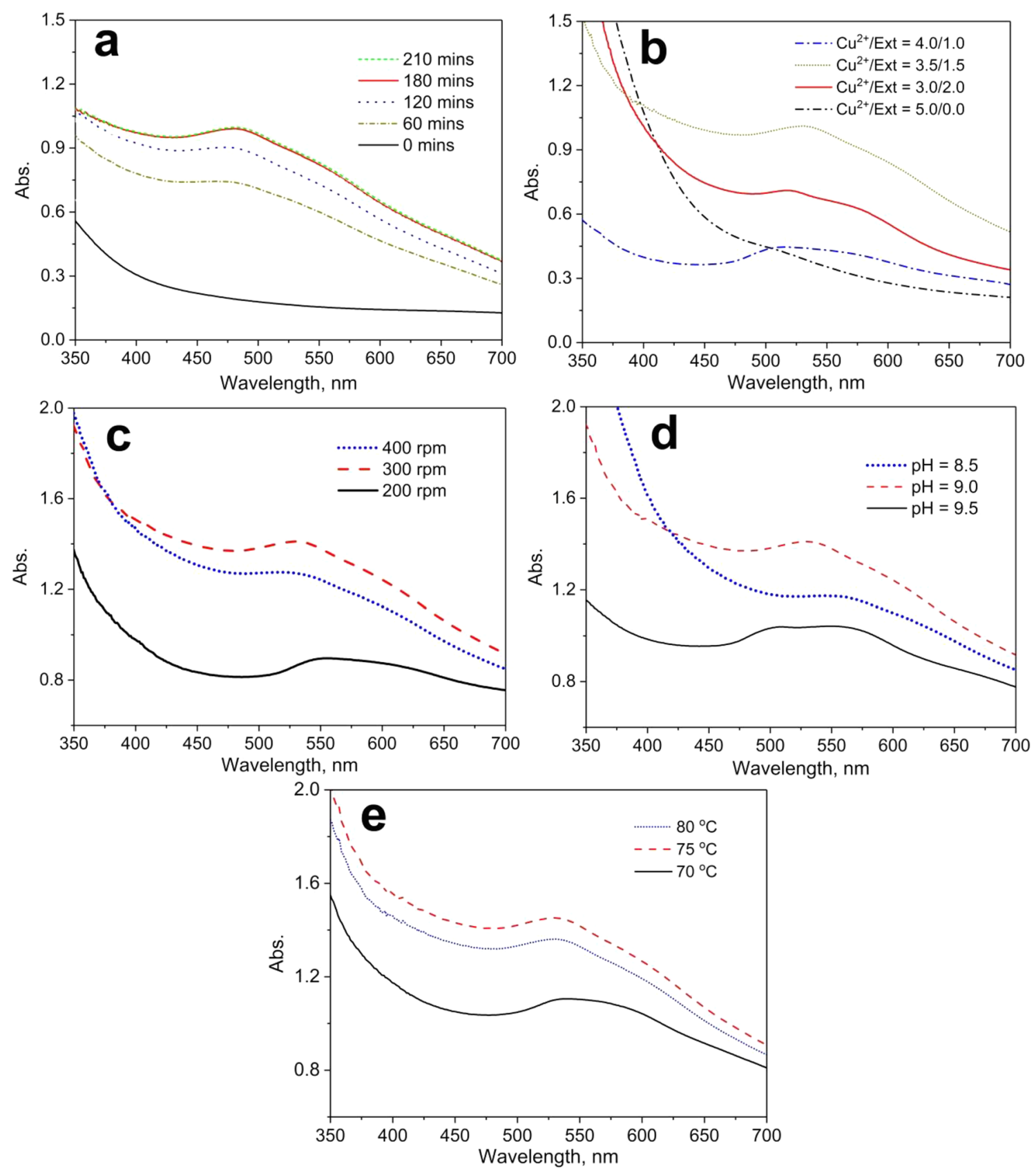

Fig. 1 UV-Vis spectra of CuNPs solutions under various conditions; a Effect of synthesis duration, $\mathbf{b}$ Effect of $\mathrm{V}_{\mathrm{Cu}+} / \mathrm{V}_{\mathrm{Ext}}$ volume ratio, $\mathbf{c}$ Effect of stirring rate, $\mathbf{d}$ Effect of $\mathrm{pH}$ solution, and $\mathbf{e}$ Effect of synthesis temperature

$2 \theta=36.2^{\circ}$ of the cuprite (111) plane was also observed [27]. Therefore, XRD analysis confirmed the presence of pure CuNPs with a highly crystalline structure. The average crystal size of the CuNPs can be calculated by the Debye-Scherrer equation with $\mathrm{K}=0.94$ at $2 \theta=43.6^{\circ}$, showing the value of $34.4 \mathrm{~nm}$. Lattice parameter was determined through interplanar spacing (d-spacing) of the (111) planes at $2 \theta=43.6^{\circ}$, as follows: $\alpha=d \sqrt{h^{2}+k^{2}+l^{2}}$

where " $a$ " is a lattice parameter $[\AA \AA], d$ is d-spacing $[\AA]]$; and $h, k$, and $I$ are the Miller indices of the (111) plane of the crystal. A d-spacing value of $2.075 \AA$ with a lattice parameter of $3.594 \AA$ for the Miller indices corresponding to (111) plane that matches well with standard lattice parameter $(a=3.615 \AA$ ) [7]. 
Fig. 2 The color changes during the synthesis of CuNPs at various synthesis duration

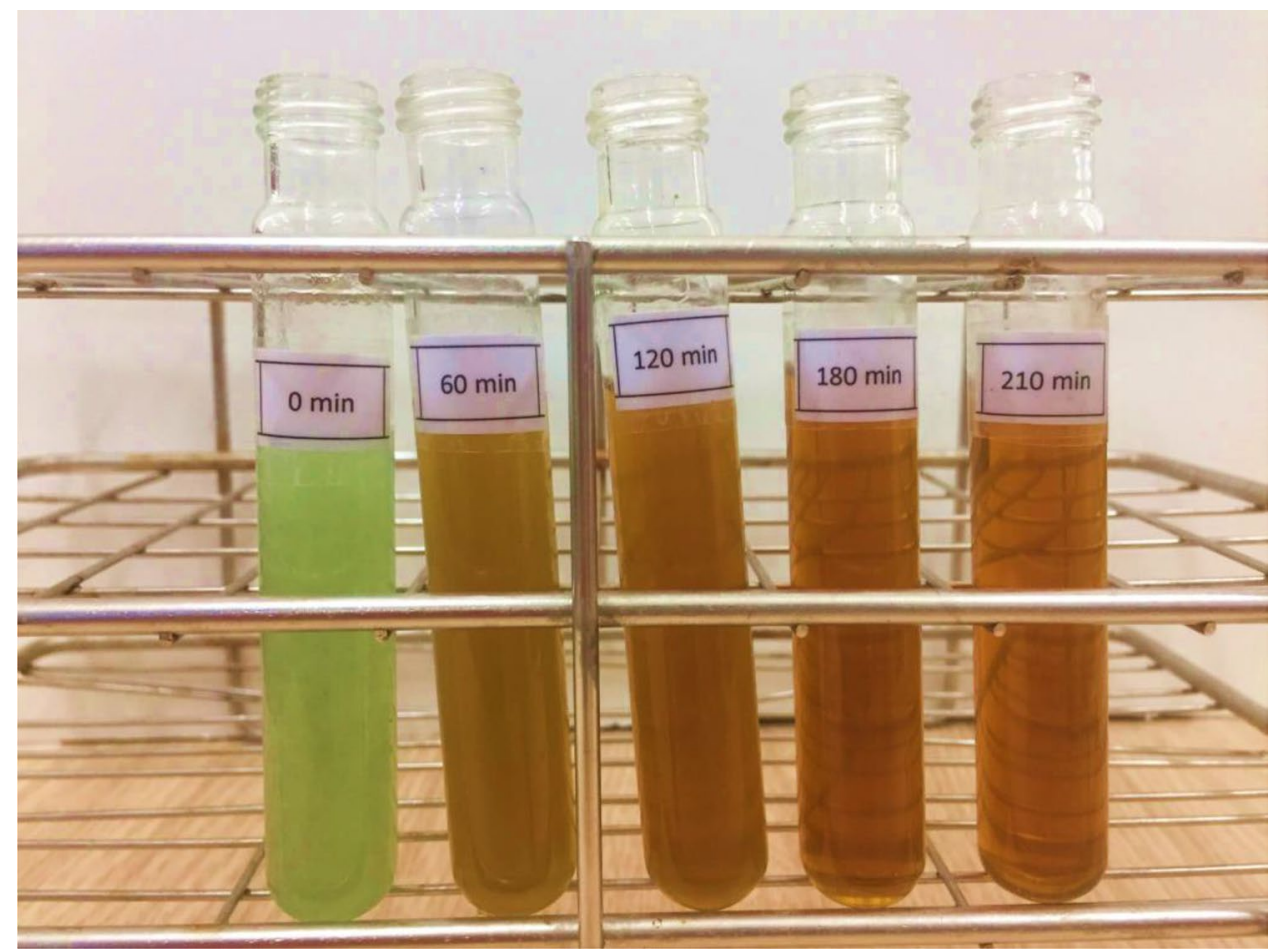

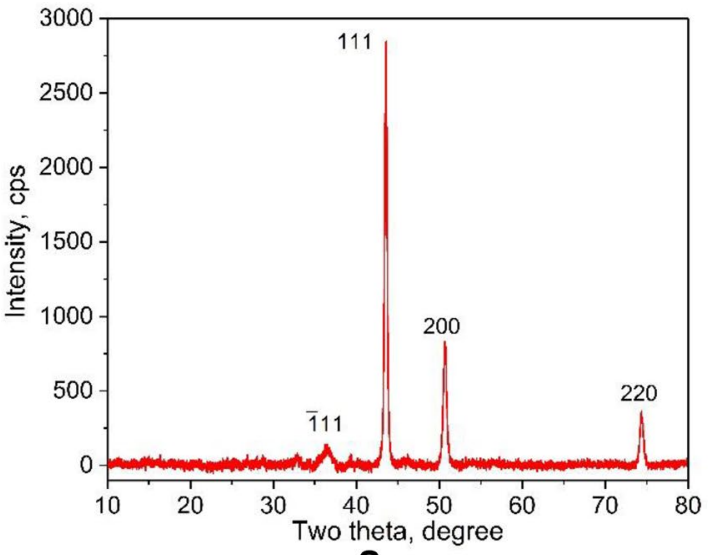

a

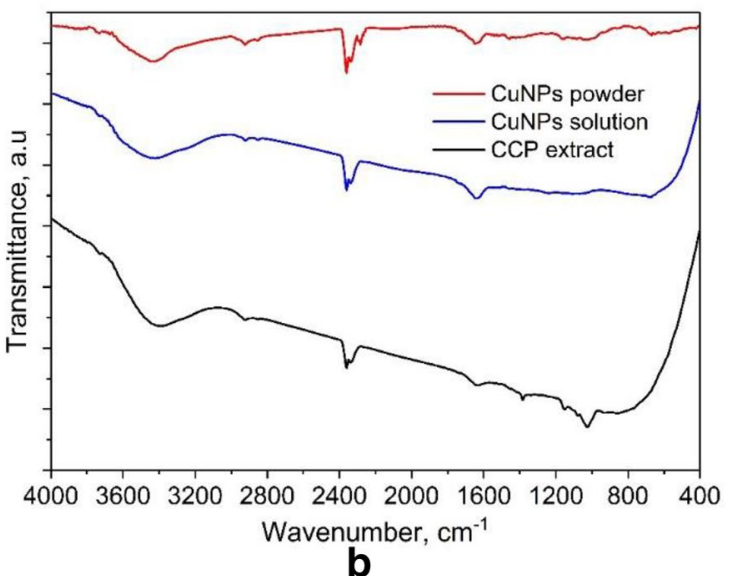

b

Fig. 3 XRD diffraction pattern of CUNPs (a) and FT-IR spectra of CCP extract and CuNPs synthesized at the optimized conditions (b)

FT-IR spectra of CCP extract, CuNPs solution, and CuNPs powder were described in Fig. 3b. For the extracted sample, FT-IR analysis is used to detect the possible bioactive molecules, which are mainly responsible for the reduction of the $\mathrm{Cu}^{2+}$ ions to CuNPs. FT-IR spectrum manifested the strong peaks at 3295,2850 , and $1640 \mathrm{~cm}^{-1}$, associated with the $\mathrm{N}-\mathrm{H}$ bond of amines $[1,9]$, the $\mathrm{C}-\mathrm{H}$ stretching, and the $\mathrm{C}=\mathrm{C}$ stretch of alkenes or $\mathrm{C}=\mathrm{O}$ stretch of amides [1], respectively. These characterized bands affirmed the presence of proteins and phenolic compounds in the extract which play the roles of the reducing and stabilizing agents. There are insignificant differences between the CCP extract and CuNPs solution, probably because the compounds of CCP extract overlapped the peaks of CuNPs surface. However, the FT-IR spectrum of CuNPs solution showed the presence of a weaker signal compared to CCP extract, proving the functional groups contained the extract reacted to form CuNPs, so the concentration of the extract was significantly reduced. On the FT-IR spectrum of CuNPs powder, a band centered at $2285 \mathrm{~cm}^{-1}$ was related to the $\mathrm{Cu}-\mathrm{H}$ stretching [34], and the peaks at 640 and $530 \mathrm{~cm}^{-1}$ corresponded to $\mathrm{Cu}-\mathrm{O}$ bond were not detected, indicating the formation of only CuNPs. From the analysis of FT-IR studies, we confirmed that the proteins and 
phenolics compounds in CCP extract possibly performed the dual functions for the formation of CuNPs.

In order to study the morphology and size of the biosynthesized CUNPs, the SEM image was shown in Fig. 4a. The result exhibited the presence of nanosized spherical particles (in the range of 20-50 nm) with a uniform particle shape, in agreement with the crystal size of CuNPs calculated from XRD pattern. HRTEM has been employed to characterize the shape, size, and morphology of the CuNPs sample. The HRTEM analysis proved the formation of nanocrystalline copper particles with spherical shape and the size was estimated in a range of $30-40 \mathrm{~nm}$ (seen in Fig. 4b). The inset in Fig. 4b demonstrated that the CuNPs had both the (111) and (200) planes of structured CuNPs with the d-spacings of 0.22 and $0.24 \mathrm{~nm}$, respectively. The results were consistent with the XRD analysis as mentioned above.

The elemental compositions of the bio-synthesized nanoparticles were determined by EDS analysis. The EDS spectrum of CuNPs synthesized at the optimized conditions is shown in Fig. 5. It shows high intense major peaks of elemental $\mathrm{Cu}$ with an atomic percentage of $75.77 \%$, which was typical for the absorption of metallic copper because of surface plasmon resonance. The appearance of weak signals of O (12.53\%) and C (11.70\%) together with strong metallic copper peak may be owing to the presence of bio-molecules that are bound to the surface of CuNPs.

\subsection{Characteristics and performance of CuNPs loaded on various supports in deep oxidation of benzene}

X-ray diffraction analyses (XRD) of the CuNPs samples loaded on various supports with the CuNPs content fixed

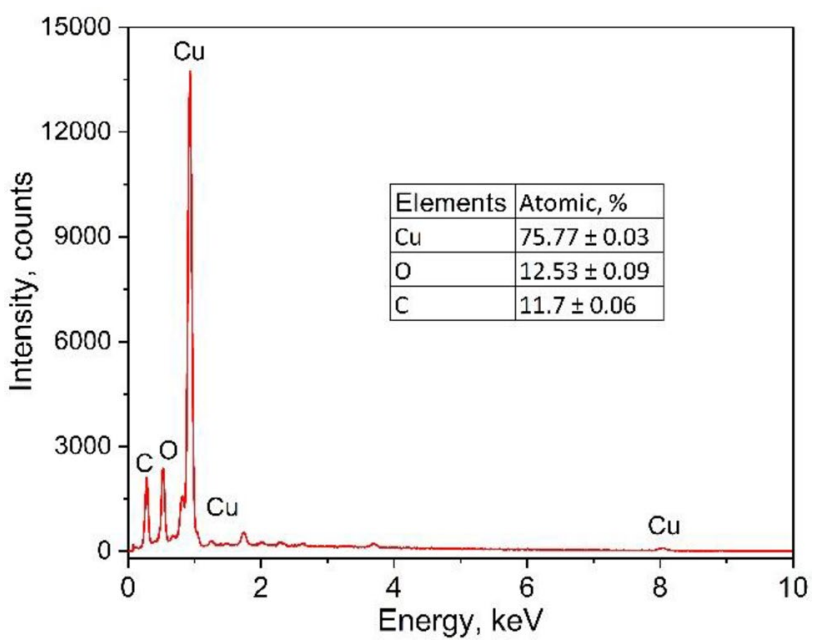

Fig. 5 EDS spectrum of CuNPs synthesized at the optimized conditions

at $5 \mathrm{wt} \%$ were shown in Fig. 6 . The crystal phases of copper $\left(\mathrm{Cu}^{\circ}\right)$ also appeared at $2 \theta=43.6^{\circ}, 50.7^{\circ}$, and $74.4^{\circ}$ on $5 \mathrm{Cu}-\mathrm{Al}, 5 \mathrm{Cu}-\mathrm{Ce}$, and $5 \mathrm{C}-\mathrm{Ti}$ samples, indicating the successful synthesis of CuNPs on such supports. The average crystal sizes of the CuNPs loaded on $\mathrm{Al}_{2} \mathrm{O}_{3}, \mathrm{CeO}_{2}$, and $\mathrm{TiO}_{2}$ were determined as $31.5,26.5$, and $27.2 \mathrm{~nm}$, respectively. It proves that the formation of CuNPs on the support surface helped to prevent the agglomeration of CuNPs, leading to reducing the size of CuNPs. In which, CuNPs with the smallest particle size were detected on $5 \mathrm{Cu}-\mathrm{Ce}$ samples, demonstrating the positive influences of $\mathrm{CeO}_{2}$ support for the dispersion of CuNPs. SEM images of $5 \mathrm{Cu}-\mathrm{Al}, 5 \mathrm{Cu}-\mathrm{Ce}$, and $5 \mathrm{Cu}-\mathrm{Ti}$ samples showed the presence of nanosized particles $(20-50 \mathrm{~nm})$ with highly porous structures Fig. 7. However, a high level of agglomeration of CuNPs was

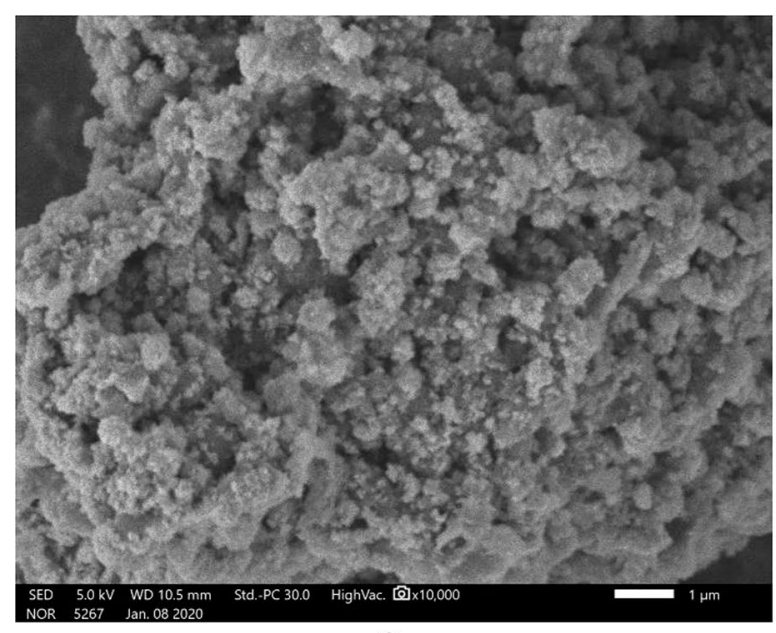

a

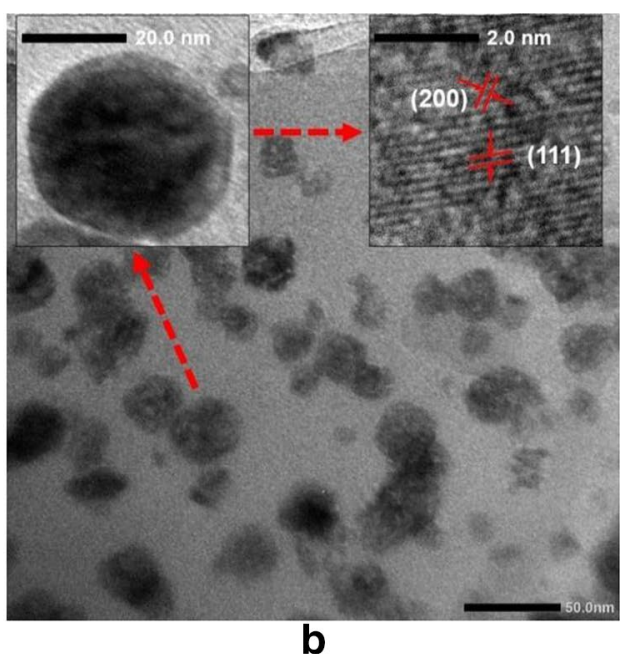

Fig. 4 SEM (a) and HRTEM (b) image of CuNPs synthesized at the optimized conditions 


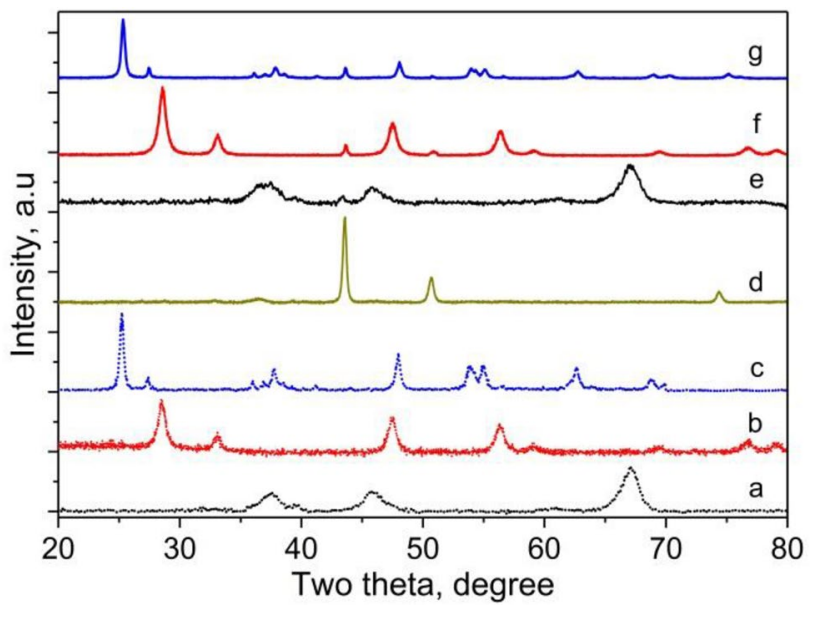

Fig. 6 XRD diffraction patterns of the samples; $\mathrm{Al}_{2} \mathrm{O}_{3}, \mathrm{~b} \mathrm{CeO}_{2}, \mathrm{C}$ $\mathrm{TiO}_{2}$, d CuNPs, e $5 \mathrm{Cu}-\mathrm{Al}$, f $5 \mathrm{Cu}-\mathrm{Ce}$, and g $5 \mathrm{Cu}-\mathrm{Ti}$ observed on the $5 \mathrm{Cu}-\mathrm{Al}$ sample, being consistent with the results from $X R D$ analyses.

Figure 8a presents the $\mathrm{N}_{2}$ adsorption-desorption isotherms of $5 \mathrm{C}-\mathrm{Al}, 5 \mathrm{C}-\mathrm{Ce}$, and $5 \mathrm{C}-\mathrm{Ti}$ samples with the filled and open symbols indicating the adsorption and desorption values, respectively. The shapes of the adsorption isotherms for three samples obey type IV, which is associated with capillary condensation in the mesopores [4, $10,40]$. It clearly shows that less nitrogen was adsorbed on $5 \mathrm{Cu}-\mathrm{Al}$ than those on $5 \mathrm{C}-\mathrm{Ce}$ and $5 \mathrm{C}-\mathrm{Ti}$. Besides, the hysteresis loop of the $5 \mathrm{C}-\mathrm{Al}$ sample did not exhibit the limiting adsorption at high $P / P^{0}$ values. This phenomenon is related to the presence of agglomerates, i.e., an assembly of particles rigidly joined together, in agreement with the SEM image of this sample. Figure $8 \mathrm{~b}$ shows the specific surface areas of catalysts are arranged in the order: $5 \mathrm{Cu}-\mathrm{Al}>5 \mathrm{Cu}-\mathrm{Ti}>5 \mathrm{Cu}-\mathrm{Ce}$. However, the pore diameter and volume of catalysts are insignificantly different.

The catalytic performances of CuNPs, supported-CuNPs, and supports were evaluated in the deep oxidation of benzene as a function of the temperature, $275-450{ }^{\circ} \mathrm{C}$ shown
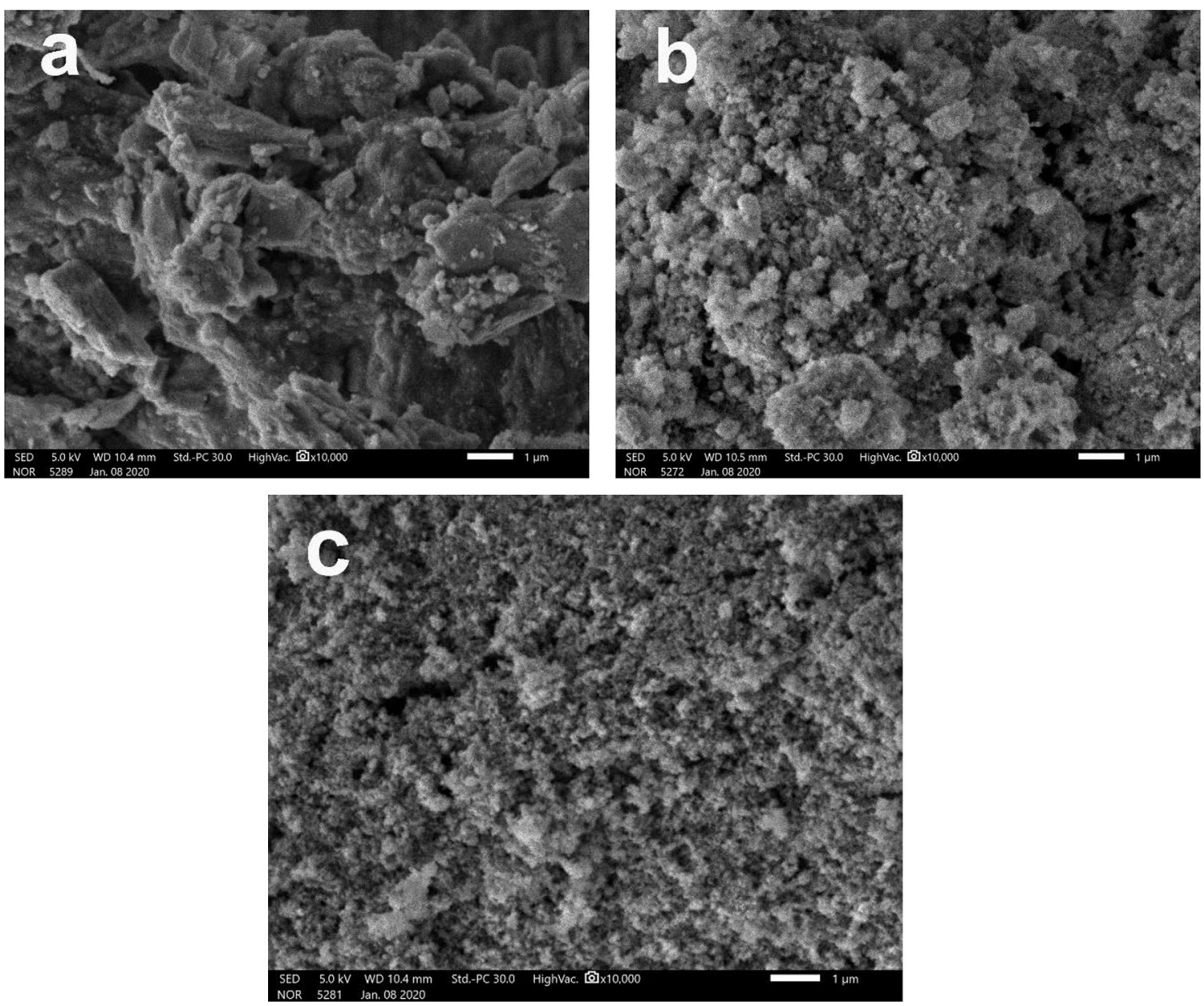

Fig. 7 SEM images of CuNPs loaded on various supports; a $5 \mathrm{Cu}-\mathrm{Al}$; b $5 \mathrm{Cu}-\mathrm{Ce}$; and $\mathbf{c} 5 \mathrm{Cu}-\mathrm{Ti}$ 


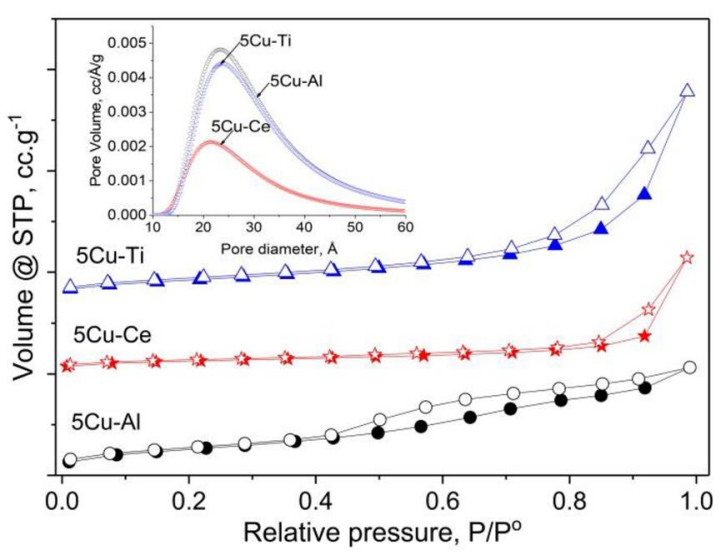

a

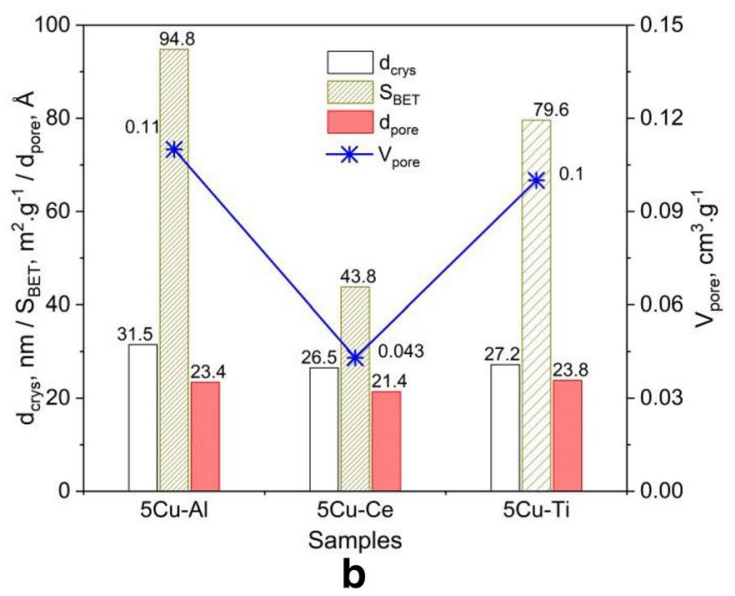

b

Fig. $8 \quad N_{2}$ adsorption/desorption isotherms $(\mathbf{a})$ and the BET surface $\left(\mathrm{S}_{\mathrm{BET}}\right)$, average pore diameter $\left(\mathrm{d}_{\text {pore }}\right)$, pore volume $\left(\mathrm{V}_{\text {pore }}\right)$ of CuNPs loaded on various supports (b)
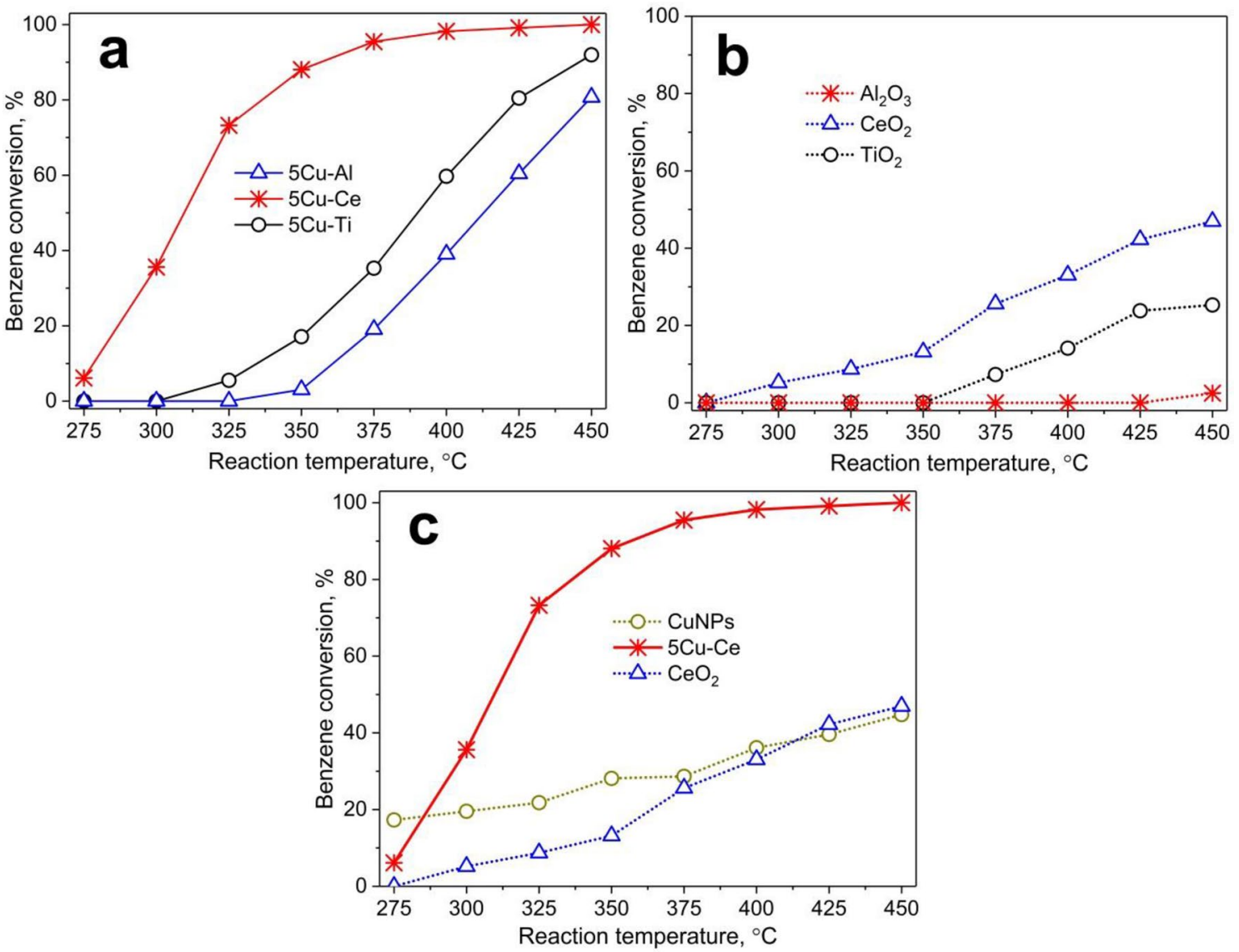

Fig. 9 The catalytic activity of different samples in benzene oxidation

in Fig. 9. The benzene deep oxidation over the CuNPs fixed at $5 \mathrm{wt} \%$ on various supports prepared by the green synthesis is shown in Fig. 9a. It was found that the steep rise in benzene conversion was taken place with higher reaction temperatures. The catalytic activity of $5 \mathrm{Cu}-\mathrm{Ce}$ sample was much higher than those of CuNPs catalyst with the same content supported on $\mathrm{TiO}_{2}$ and $\mathrm{Al}_{2} \mathrm{O}_{3}$ Fig. 9a, although its specific surface area is the smallest among three catalysts. Benzene conversion on $5 \mathrm{Cu}-\mathrm{Ce}$ catalyst reached above $90 \%$ at $375^{\circ} \mathrm{C}$. Besides that, pure $\mathrm{CeO}_{2}$ has a much higher 
activity than $\mathrm{TiO}_{2}$ and $\mathrm{Al}_{2} \mathrm{O}_{3}$ supports Fig. $9 \mathrm{~b}$. This can be explained that, in the catalytic process, $\mathrm{CeO}_{2}$ serves as an oxygen supplier through either the formation of superoxide species $\left(\mathrm{O}^{2-}\right)$ by gas-phase oxygen reacting with oxygen vacancies on its surface or the direct involvement of lattice oxygen. Furthermore, the oxygen vacancies are easily formed in the $\mathrm{CeO}_{2}$ support due to its high oxygen mobility to favor catalytic activity. The pure CuNPs sample was also relatively active in the benzene deep oxidation, reaching nearly $50 \%$ conversion of benzene at $450^{\circ} \mathrm{C}$. However, compared to the composite of CuNPs and $\mathrm{CeO}_{2}(5 \mathrm{Cu}-\mathrm{Ce})$, the pure $\mathrm{CuNPs}$ and $\mathrm{CeO}_{2}$ catalysts clearly showed much lower activities Fig. 9 c.

It is well known that the $\mathrm{Cu}-\mathrm{Ce}$ composite is one of the most important heterogeneous catalysts, widely used in catalytic oxidations [2-3,20,37], in particular the deep oxidation of benzene, toluene and xylene (Urbutis et al. 2014). Their high activity is attributed to the high oxygen storage capacity of ceria, the facile $\mathrm{Ce}^{4+} / \mathrm{Ce}^{3+}$ redox cycle, and the synergistic effect between $\mathrm{Cu}$ and $\mathrm{CeO}_{2}$ [23].

\subsection{Determination of the suitable CuNPs loaded on $\mathrm{CeO}_{2}$ and its catalytic performance in deep oxidation of various aromatic hydrocarbons}

XRD patterns of the CuNPs supported on $\mathrm{CeO}_{2}$ (with different copper loadings) were displayed in Fig. 10. Clearly, the crystal phases of CuNPs also appeared on CuNPs- $\mathrm{CeO}_{2}$ with various $\mathrm{Cu}$ contents, indicating the successful synthesis of CuNPs loaded on $\mathrm{CeO}_{2}$. The average crystal sizes of $5 \mathrm{Cu}-\mathrm{Ce}, 7.5 \mathrm{Cu}-\mathrm{Ce}$, and $10 \mathrm{Cu}-\mathrm{Ce}$ catalysts were 26.5 , 27.3 , and $29.6 \mathrm{~nm}$, respectively Fig. 9 . It could be explained that the crystallite size of the CuNPs slightly increased when increasing the contents of CuNPs loaded on $\mathrm{CeO}_{2}$

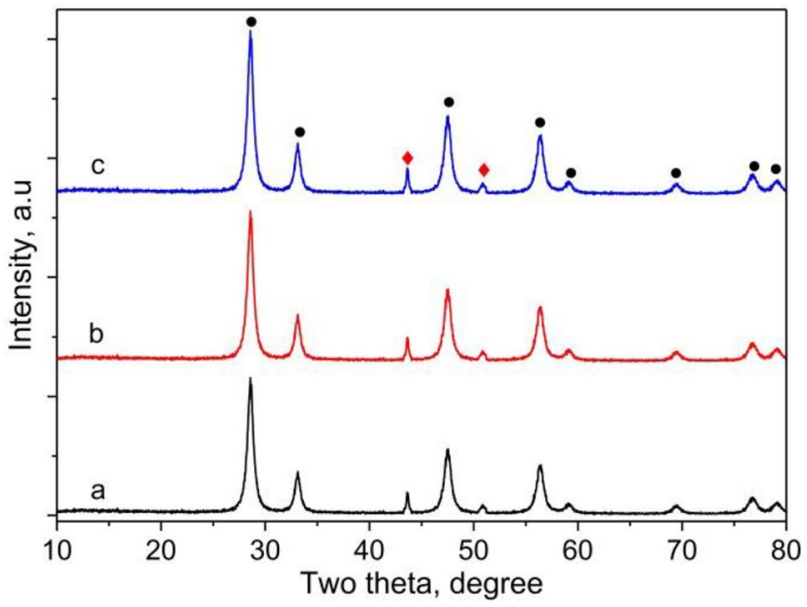

Fig. 10 XRD diffraction patterns of the CuNPs supported on $\mathrm{CeO}_{2}$ (circle: $\mathrm{CeO}_{2}$ and diamond: $\mathrm{Cu}$ ). a $5 \mathrm{Cu}-\mathrm{Ce}$, b $7.5 \mathrm{Cu}-\mathrm{Ce}$, and c $10 \mathrm{Cu}-$ $\mathrm{Ce}$ support. The crystallite sizes of the CuNPs supported on $\mathrm{CeO}_{2}$ samples were also smaller than that of the pure CUNPs. The comparison of BET specific surface area, average pore diameter, and pore volume are also exhibited in Fig. 11. The differences between $5 \mathrm{Cu}-\mathrm{Ce}$ and $7.5 \mathrm{Cu}-\mathrm{Ce}$ samples were negligible. Compared with $10 \mathrm{Cu}-\mathrm{Ce}$, the $7.5 \mathrm{Cu}-\mathrm{Ce}$ catalyst had a higher BET surface area ( $40.9 \mathrm{vs.}$ $\left.28.5 \mathrm{~m}^{2} \mathrm{~g}^{-1}\right)$, a larger pore volume $\left(0.15 \mathrm{vs} .0 .11 \mathrm{~cm}^{3} \mathrm{~g}^{-1}\right)$ and larger pore diameter $\left(10.3\right.$ vs. $\left.9.2 \mathrm{~cm}^{3} \mathrm{~g}^{-1}\right)$. Furthermore, $7.5 \mathrm{Cu}-\mathrm{Ce}$ catalyst showed higher porous and smaller nanoparticles than $10 \mathrm{Cu}-\mathrm{Ce}$ sample, leading to a better catalytic performance in BTEX deep oxidation.

HR-TEM analysis was performed to investigate the microstructural characteristics of $7.5 \mathrm{Cu}-\mathrm{Ce}$ sample Fig. 12. The HR-TEM image confirmed the stability of $\mathrm{CeO}_{2}$ nanorods after $\mathrm{Cu}$ addition. The $\mathrm{CeO}_{2}$ nanorods were 20-30 nm in diameter and 100-200 nm in length. The inset below in Fig. 12 demonstrated that $\mathrm{CeO}_{2}$ nanorods exposed both the (100) and (110) planes of structured fluorite $\mathrm{CeO}_{2}$ with the d-spacings of 0.25 and $0.27 \mathrm{~nm}$, respectively. Besides, the HR-TEM analysis also indicated that the formation of cubic particles of the CuNPs was exposed to $\mathrm{CeO}_{2}$ nanorods. The estimated d-spacings of 0.25 and $0.29 \mathrm{~nm}$ (inset above Fig. 12) were assigned to the (111) and (200) crystal planes of CuNPs phase in 7.5Cu-Ce sample, respectively. The particle size of CuNPs has been estimated in the range of $30-40 \mathrm{~nm}$. These analyses were entirely consistent with the corresponding XRD analysis.

The effect of CuNPs loading on the catalytic activity in benzene deep oxidation was investigated and shown in Fig. 13. The conversion of benzene was dramatically raised when reaction temperature increased from 275 to $360^{\circ} \mathrm{C}$ and almost completed at $400^{\circ} \mathrm{C}$ for all $\mathrm{Cu}-\mathrm{Ce}$

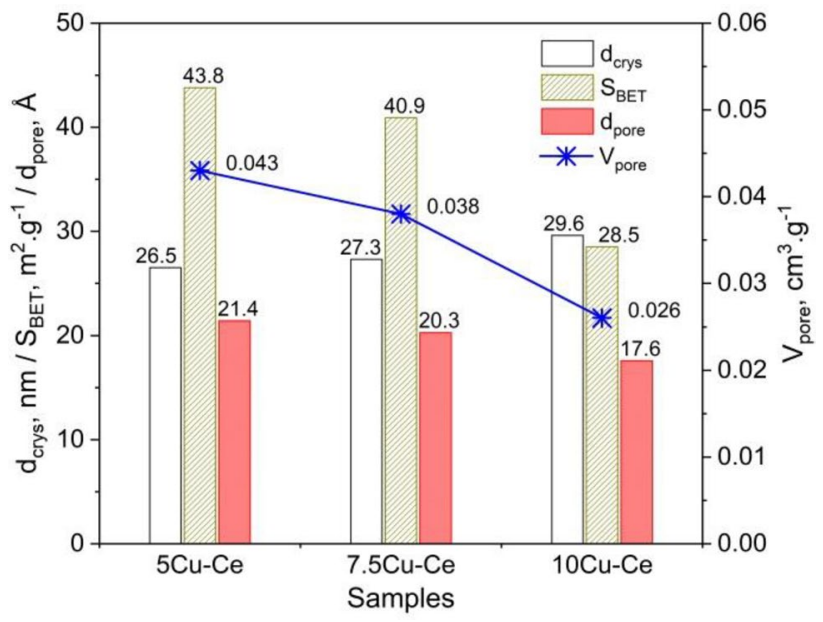

Fig. 11 The comparison of BET surface $\left(\mathrm{S}_{\mathrm{BET}}\right)$, average pore diameter $\left(\mathrm{d}_{\text {pore }}\right)$, pore volume $\left(\mathrm{V}_{\text {pore }}\right)$ and the average diameter of CuNPs $\left(\mathrm{d}_{\text {crys }}\right)$ based on XRD results at $2 \square=36.1^{\circ}$ of samples 


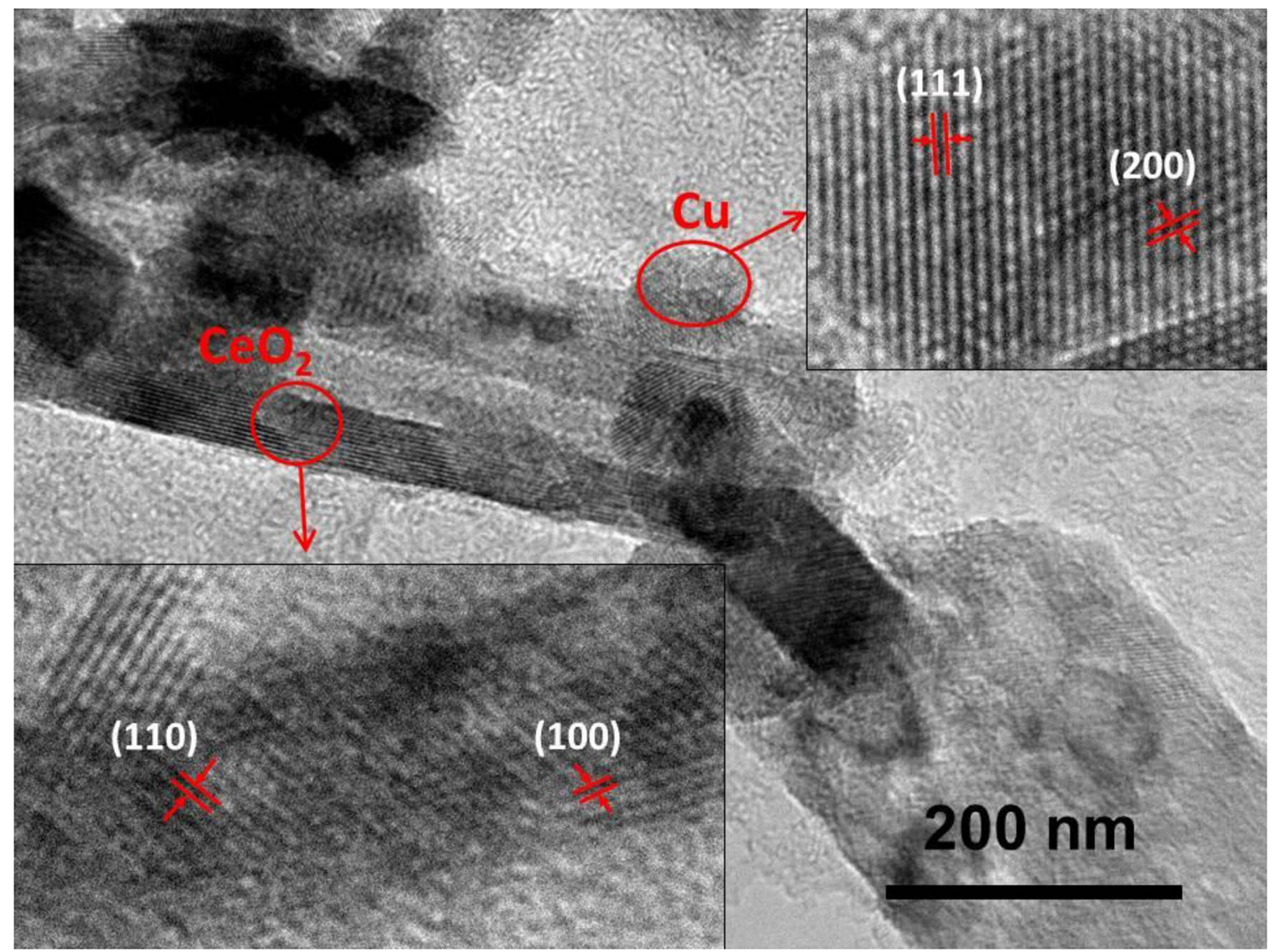

Fig. 12 HR-TEM image of 7.5 wt\% CuNPs sample loaded on $\mathrm{CeO}_{2}$

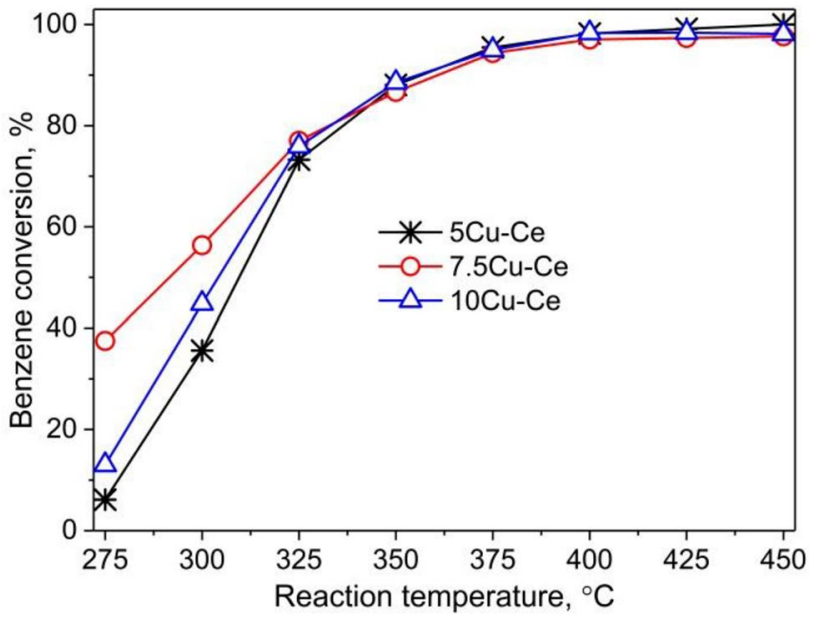

Fig. 13 The catalytic activity in benzene oxidation of CuNPs loaded on $\mathrm{CeO}_{2}$ with different copper contents

catalysts. Their light-off temperatures (at $50 \%$ benzene conversion, $\mathrm{T}_{50}$ ) on $5 \mathrm{Cu}-\mathrm{Ce}, 7.5 \mathrm{Cu}-\mathrm{Ce}$, and $10 \mathrm{Cu}-\mathrm{Ce}$ catalysts occurred at 310,290 , and $305^{\circ} \mathrm{C}$, respectively. Obviously, the $7.5 \mathrm{Cu}-\mathrm{Ce}$ sample was the most efficient,

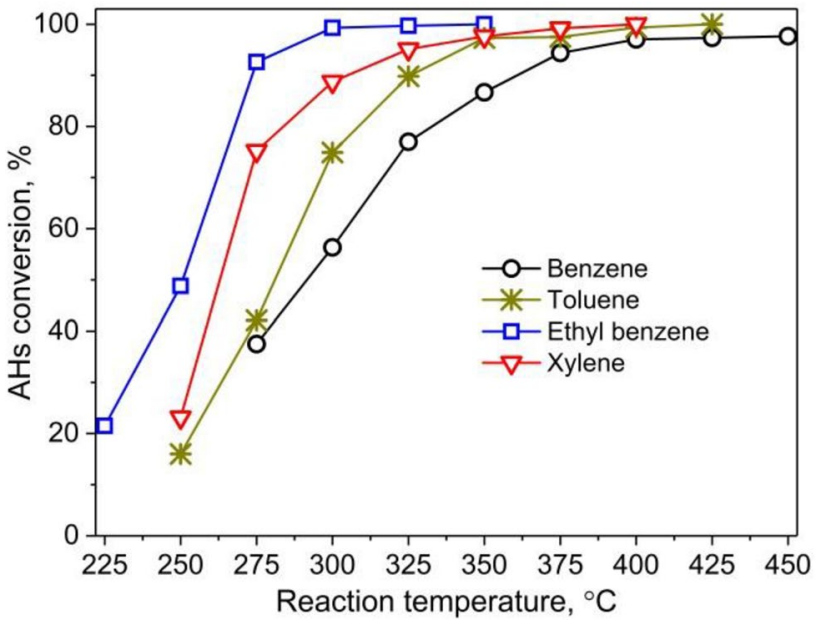

Fig. 14 The activity of 7.5Cu-Ce catalyst in deep oxidation of various aromatic hydrocarbons

reaching a higher benzene conversion at a low temperature $\left(275-325^{\circ} \mathrm{C}\right)$. Therefore, the suitable CuNPs loading on $\mathrm{CeO}_{2}$ was 7.5 wt $\%$.

\section{SN Applied Sciences}



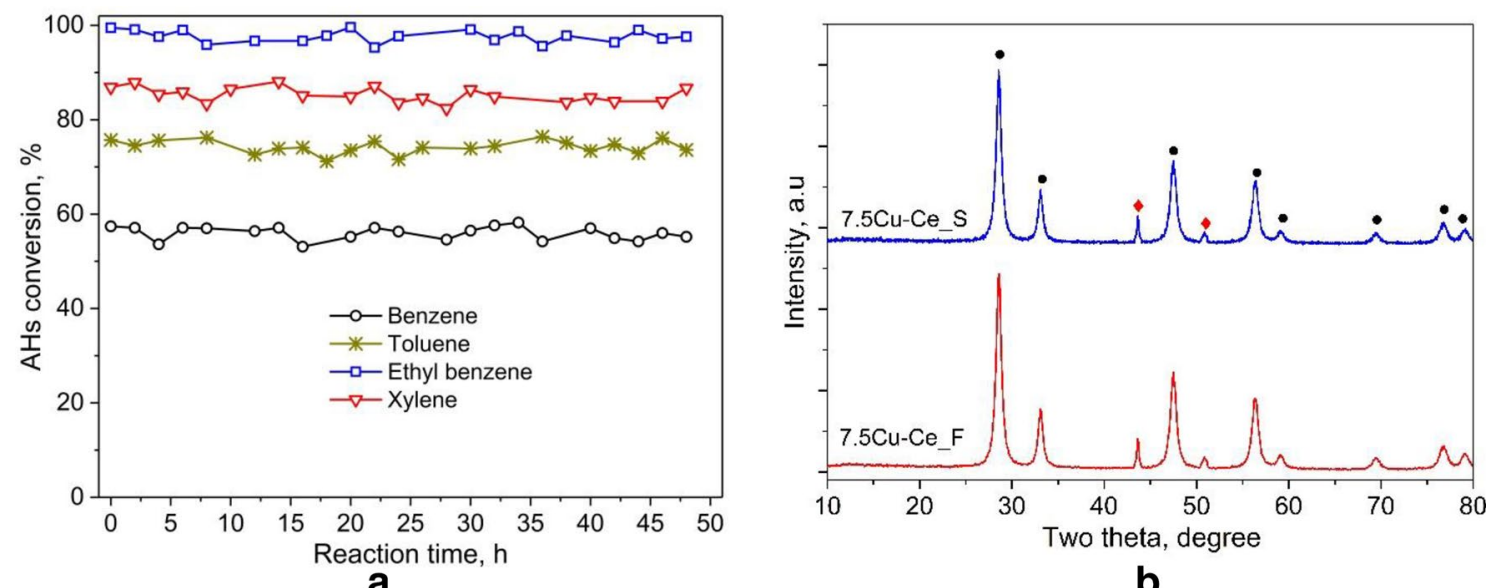

b

Fig. 15 The stability of $7.5 \mathrm{Cu}$-Ce catalyst in deep oxidation of various aromatic hydrocarbons at $300{ }^{\circ} \mathrm{C}$ during $48 \mathrm{~h}(\mathbf{a})$ and XRD pattern of fresh and spent 7.5 Cu-Ce catalysts (circle: $\mathrm{CeO}_{2}$ and diamond $\mathrm{Cu}$ ) (b)

The most efficient catalyst $(7.5 \mathrm{Cu}-\mathrm{Ce})$ was further investigated in BTEX oxidation Fig. 14. The conversion of ethylbenzene was higher than those of benzene, toluene, and xylene. Evidently, the catalytic activity of all samples increased in the order: benzene $<$ toluene $<$ xylene $<$ ethylbenzene. This consequence confirmed that the catalytic activity for the treatment of aromatic compounds highly relies on the strength of the weakest $\mathrm{C}-\mathrm{H}$ bond in the structure, the ionization potential of methyl derivatives, and relative adsorption strength of model compounds $[25$, 32]. In which, the complete conversion of ethylbenzene took place at $350^{\circ} \mathrm{C}$; meanwhile, the temperatures for the complete conversions of xylene, toluene, and benzene were 400,425 , and $450^{\circ} \mathrm{C}$, respectively.

The 7.5Cu-Ce sample was selected to investigate the activity stability in $\mathrm{AHs}$ oxidation at $300^{\circ} \mathrm{C}$. The conversions of benzene, toluene, ethylbenzene, and xylene were unchanged for $48 \mathrm{~h}$ at $300^{\circ} \mathrm{C} \mathrm{Fig.} 15 \mathrm{a}$, indicating the great stability of the $7.5 \mathrm{Cu}-\mathrm{Ce}$ sample in such processes. It can be explained that the $\mathrm{CeO}_{2}$ support with the advantage of redox property can be easily adjusted between reducing and oxidizing states that cause the donation and reception of oxygen, resulting in the oxidation of hydrocarbons at high temperatures. Besides, $\mathrm{CeO}_{2}$ can also adsorb and desorb $\mathrm{H}_{2} \mathrm{O}$ to generate the $\mathrm{O}^{-}$and $\mathrm{OH}^{-}$species, converting the hydrocarbons on catalyst surface into $\mathrm{CO}$ and $\mathrm{CO}_{2}$ [41], and thus enhancing the stability of the 7.5Cu-Ce catalyst. The XRD result Fig. $15 \mathrm{~b}$ of the spent catalysts (7.5Cu-Ce_S) showed that the phase composition of both samples was almost unchanged compared to the fresh one (7.5Cu-Ce_F). This proved that the structure of the catalyst was not damaged under reaction conditions at a temperature of $300^{\circ} \mathrm{C}$ for $48 \mathrm{~h}$.

\section{Conclusion}

The green synthesis of CuNPs and CuNPs loaded on various supports $\left(\mathrm{Al}_{2} \mathrm{O}_{3}, \mathrm{CeO}_{2}\right.$, and $\left.\mathrm{TiO}_{2}\right)$ using Cocoa pod extract as a reducing agent proved to be an efficient and rapid approach towards BTEX deep oxidation. The catalyst characterizations confirmed the formation of highly crystalline sphere-shaped CuNPs with the size in a range of 20-50 nm. The formation of CuNPs on the support surface permitted to prevent the agglomeration of CuNPs and reduce their size, leading to enhancing their catalytic activity in BTEX deep oxidation. It was interesting to find out that the $7.5 \mathrm{wt} \%$ of $\mathrm{CuNPs}$ supported on $\mathrm{CeO}_{2}$ exhibited the best catalytic performance towards BTEX deep oxidation. Hence, CuNPs and supported-CuNPs synthesized using plant-derived extracts (like Cocoapods) as reducing agents can be the promising approach in the development of catalytic systems for the aromatic hydrocarbons oxidation processes.

Acknowledgements This study was funded by The Youth Incubator for Science and Technology Program, managed by Youth Development Science and Technology Center-Ho Chi Minh Communist Youth Union and Department of Science and Technology of Ho Chi Minh City (Grant Number 22/2019/HĐ-KHCNT-VU').

\section{Compliance with ethical standards}

Conflict of interest The authors declare that they have no conflict of interest. 


\section{References}

1. Adjin-Tetteh M, Asiedu N, Dodoo-Arhin D, Karam A, Amaniampong PN (2018) Thermochemical conversion and characterization of cocoa pod husks a potential agricultural waste from Ghana. Indl Crop Prod 119:304-312. https://doi.org/10.1016/j. indcrop.2018.02.060

2. Avgouropoulos G, loannides T, Matralis HK, Batista J, Hocevar $\mathrm{S}$ (2001) $\mathrm{CuO}-\mathrm{CeO}_{2}$ mixed oxide catalysts for the selective oxidation of carbon monoxide in excess hydrogen. Catal Letters 73:33-40. https://doi.org/10.1023/A:1009013029842

3. Avgouropoulos G, loannides T, Papadopoulou C, Batista J, Hocevar S, Matralis H (2002) A comparative study of $\mathrm{Pt} / \mathrm{Y}^{-}$ $\mathrm{Al}_{2} \mathrm{O}_{3}, \mathrm{Au} / \mathrm{a}-\mathrm{Fe}_{2} \mathrm{O}_{3}$ and $\mathrm{CuO}-\mathrm{CeO}_{2}$ catalysts for the selective oxidation of carbon monoxide in excess hydrogen. Catal Today 75:157-167. https://doi.org/10.1016/S0920-5861(02)00058-5

4. Ayodele BV, Khan MR, Cheng CK (2016) Production of CO-rich hydrogen gas from methane dry reforming over $\mathrm{Co} / \mathrm{CeO} 2$ catalyst. Bull Chem React Eng Catal 11:210-219. https://doi. org/10.9767/bcrec.11.2.552.210-219

5. Bossi R, Kolarik J, Wargocki P, Lyng N, Witterseh T, Skov H (2019) Chemical characterization of volatile organic compounds emitted from selected indoor activities. Conference Series 185

6. Chen C-L, Fang HY, Shu C-M (2005) Source location and characterization of volatile organic compound emissions at a petrochemical plant in Kaohsiung. Taiwan J Air Waste Manage 55:1487-1497. https://doi.org/10.1080/10473289.2005.10464 741

7. Diaz-Droguett DE, Espinoza R, Fuenzalida V (2011) Copper nanoparticles grown under hydrogen: study of the surface oxide. Appl Surf Sci 257:4597-4602. https://doi.org/10.1016/j. apsusc.2010.12.082

8. Donkoh A, Atuahene C, Wilson B, Adomako D (1991) Chemical composition of cocoa pod husk and its effect on growth and food efficiency in broiler chicks. Ani Feed Sci Tech 35:161-169. https://doi.org/10.1016/0377-8401(91)90107-4

9. Ebrahimi K, Shiravand S, Mahmoudvand H (2017) Biosynthesis of copper nanoparticles using aqueous extract of Capparis spinosa fruit and investigation of its antibacterial activity. Marmara Pharm J 21:866-871. https://doi.org/10.12991/mpj.2017.31

10. Fang D, Ren W, Liu Z, Xu X, Xu L, Lü H, Liao W, Zhang H (2009) Synthesis and applications of mesoporous $\mathrm{Cu}-\mathrm{Zn}-\mathrm{Al}_{2} \mathrm{O}_{3}$ catalyst for dehydrogenation of 2-butanol. J Nat Gas Chem 18:179-182. https://doi.org/10.1016/S1003-9953(08)60099-7

11. Fung AG, Rajapakse MY, McCartney MM, Falcon AK, Fabia FM, Kenyon NJ, Davis CE (2019) Wearable environmental monitor to quantify personal ambient volatile organic compound exposures. ACS Sensors 4:1358-1364. https://doi.org/10.1021/ acssensors.9b00304

12. Hemmati S, Barkey DP (2017) Parametric study, sensitivity analysis, and optimization of polyol synthesis of silver nanowires. ECS J Solid State Sci Technol 6:132-137. https:// doi.org/10.1149/2.0141704jss

13. Kamal MS, Razzak SA, Hossain MM (2016) Catalytic oxidation of volatile organic compounds (VOCs): a review. Atmosc Envir 140:117-134. https://doi.org/10.1016/j.atmosenv.2016.05.031

14. Kiranmai M, Kadimcharla K, Keesara NR, Fatima SN, Bommena P, Batchu UR (2017) Green synthesis of stable copper nanoparticles and synergistic activity with antibiotics. Indian J Pharm Sci 79:695-700. https://doi.org/10.4172/pharmaceutical-scien ces. 1000281

15. Khan A, Rashid A, Younas R, Chong R (2016) A chemical reduction approach to the synthesis of copper nanoparticles. Int Nano Lett 6:21-26. https://doi.org/10.1007/s40089-015-0163-6
16. Lateef A, Azeez MA, Asafa TB, Yekeen TA, Akinboro A, Oladipo IC, Azeez L, Ojo SA, Gueguim-Kana EB, Beukes LS (2016) Cocoa pod husk extract-mediated biosynthesis of silver nanoparticles: its antimicrobial, antioxidant and larvicidal activities. J Nanostructure Chem 6:159-169

17. Le TM, An HTQ, Huu TP (2018) Synthesis of copper-based nanoparticle catalysts by different methods for total oxidation of VOC. Vietnam J Sci Technol 56:228. https://doi.org/10.15625 /2525-2518/56/3B/12776

18. Lei B, Liu B, Zhang H, Yan L, Xie H, Zhou G (2020) CuO-modified activated carbon for the improvement of toluene removal in air. J Environ Sci 88:122-132. https://doi.org/10.1016/j. jes.2019.07.001

19. Li J, Zhou Y, Simayi M, Deng Y, Xie S (2019) Spatial-temporal variations and reduction potentials of volatile organic compound emissions from the coking industry in China. J Clean Prod 214:224-235. https://doi.org/10.1016/j.jclepro.2018.12.308

20. Lin R, Luo M-F, Zhong Y-J, Yan Z-L, Liu G-Y, Liu W-P (2003) Comparative study of $\mathrm{CuO} / \mathrm{Ce} 0.7 \mathrm{SnO} 0.3 \mathrm{O}_{2}, \mathrm{CuO} / \mathrm{CeO}_{2}$ and $\mathrm{CuO} / \mathrm{SnO}_{2}$ catalysts for low-temperature $\mathrm{CO}$ oxidation. Appl Catal A Gen 255:331-336. https://doi.org/10.1016/S0926-860X(03)00639-2

21. Liu F, Csetenyi L, Gadd GM (2019) Amino acid secretion influences the size and composition of copper carbonate nanoparticles synthesized by ureolytic fungi. Appl Microbiol Biotechnol 103:7217-7230. https://doi.org/10.1007/s00253-019-09961-2

22. Liu Y, Misztal PK, Xiong J, Tian Y, Arata C, Weber RJ, Nazaroff WW, Goldstein AH (2019) Characterizing sources and emissions of volatile organic compounds in a northern California residence using space-and time-resolved measurements. Indoor Air 29:630-644. https://doi.org/10.1111/ina.12562

23. Luo M-F, Ma J-M, Lu J-Q, Song Y-P, Wang Y-J (2007) High-surface area $\mathrm{CuO}-\mathrm{CeO}_{2}$ catalysts prepared by a surfactant-templated method for low-temperature CO oxidation. J Catal 246:52-59. https://doi.org/10.1016/j.jcat.2006.11.021

24. Nasrollahzadeh M, Sajadi SM, Rostami-Vartooni A, Bagherzadeh M (2015) Green synthesis of Pd/CuO nanoparticles by Theobromacacao $\mathrm{L}$. seeds extract and their catalytic performance for the reduction of 4-nitrophenol and phosphine-free Heck coupling reaction under aerobic conditions. J Colloid Interface Sci 448:106-113. https://doi.org/10.1016/j.jcis.2015.02.009

25. O'malley A, Hodnett B (1999) The influence of volatile organic compound structure on conditions required for total oxidation. Catal Today 54:31-38. https://doi.org/10.1016/S0920 $-5861(99) 00166-2$

26. Patterson AL (1939) The scherrer formula for X-ray particle size determination. Phys Rev 56:978-982. https://doi.org/10.1103/ PhysRev.56.978

27. Raffi M, Mehrwan S, Bhatti TM, Akhter Jl, Hameed A, Yawar W, ul Hasan MM (2010) Investigations into the antibacterial behavior of copper nanoparticles against Escherichia coli. Ann Microbiol 60:75-80. https://doi.org/10.1007/s13213-010-0015-6

28. Rashidi R, Yousefinejad S, Mokarami H (2019) Catalytic ozonation process using $\mathrm{CuO} / \mathrm{clinoptilolite}$ zeolite for the removal of formaldehyde from the air stream. Int J Environ Sci Technol 16:6629-6636. https://doi.org/10.1007/s13762-018-2059-2

29. Rastogi L, Arunachalam J (2013) Green synthesis route for the size controlled synthesis of biocompatible gold nanoparticles using aqueous extract of garlic (Allium sativum). Adv Mater Lett 4:548-555. https://doi.org/10.5185/amlett.2012.11456

30. Roy NK, Foong CS, Cullinan MA (2018) Effect of size, morphology, and synthesis method on the thermal and sintering properties of copper nanoparticles for use in microscale additive manufacturing processes. Addit Manuf 21:17-29. https://doi. org/10.1016/j.addma.2018.02.008

31. Roy R, Haak L, Li L, Pagilla K (2016) Anaerobic digestion for solids reduction and detoxification of refinery waste streams. 
Process Biochem 51:1552-1560. https://doi.org/10.1016/j.procb io.2016.08.006

32. Shim WG, Kim SC (2010) Heterogeneous adsorption and catalytic oxidation of benzene, toluene and xylene over spent and chemically regenerated platinum catalyst supported on activated carbon. Appl Surf Sci 256:5566-5571. https://doi. org/10.1016/j.apsusc.2009.12.148

33. Snyder CA (2017) Experimental benzene toxicity. Benzene carcinog 29-38.

34. Srivastava A, Dwivedi K (2018) Formulation and characterization of copper nanoparticles using nerium odorum soland leaf extract and its antimicrobial activity. Int J Drug Dev Res 10:29-34

35. Tong R, Yang Y, Shao G, Zhang Y, Dou S, Jiang W (2019) Emission sources and probabilistic health risk of volatile organic compounds emitted from production areas in a petrochemical refinery in Hainan, China. Hum Ecol Risk Assess 26:1407-1427. https://doi.org/10.1080/10807039.2019.1579049

36. Urbutis A, Kitrys S (2014) Dual function adsorbent-catalyst $\mathrm{CuO}-\mathrm{CeO}_{2} / \mathrm{NaX}$ for temperature swing oxidation of benzene, toluene and xylene. Cent Eur J Chem 12:492-501. https://doi. org/10.2478/s11532-013-0398-x

37. Wang Z, Qu Z, Quan X, Li Z, Wang H, Fan R (2013) Selective catalytic oxidation of ammonia to nitrogen over $\mathrm{CuO}-\mathrm{CeO}_{2}$ mixed oxides prepared by surfactant-templated method. Appl Catal B-Envir 134:153-166. https://doi.org/10.1016/j.apcat b.2013.01.029
38. Zhang Z, Jiang Z, Shangguan W (2016) Low-temperature catalysis for VOCs removal in technology and application: a state-of-the-art review. Catal Today 264:270-278. https://doi. org/10.1016/j.cattod.2015.10.040

39. Zhang Z, Wang H, Chen D, Li Q, Thai P, Gong D, Li Y, Zhang C, Gu Y, Zhou L (2017) Emission characteristics of volatile organic compounds and their secondary organic aerosol formation potentials from a petroleum refinery in Pearl River Delta, China. Sci Total Envir 584:1162-1174. https://doi.org/10.1016/j.scito tenv.2017.01.179

40. Zheng J-Y, Pang J-B, Qiu K-Y, Wei Y (2001) Synthesis of mesoporous titanium dioxide materials by using a mixture of organic compounds as a non-surfactant template. J Mater Chem 11:3367-3372. https://doi.org/10.1039/B105907F

41. Zhuang Q, Qin Y, Chang L (1991) Promoting effect of cerium oxide in supported nickel catalyst for hydrocarbon steamreforming. Appl Catal 70:1-8. https://doi.org/10.1016/S0166 $-9834(00) 84149-4$

Publisher's Note Springer Nature remains neutral with regard to jurisdictional claims in published maps and institutional affiliations. 